
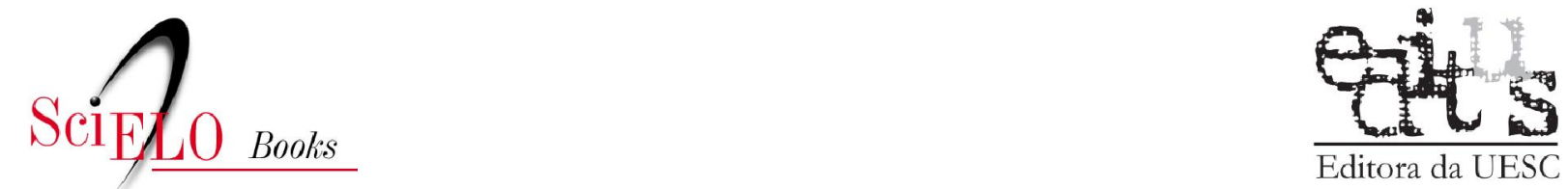

Editora da UESC

\title{
13 Ações positivas para conservação e restauração da Mata Atlântica nos estados e municípios
}

\author{
Danilo Sette de Almeida
}

\section{SciELO Books / SciELO Livros / SciELO Libros}

ALMEIDA, DS. Ações positivas para conservação e restauração da Mata Atlântica nos estados e municípios. In: Recuperação ambiental da Mata Atlântica [online].3rd ed. rev. and enl. Ilhéus, BA: Editus, 2016, pp. 184-188. ISBN 978-85-7455-440-2. Available from SciELO Books $<\underline{\text { http://books.scielo.org }>\text {. }}$

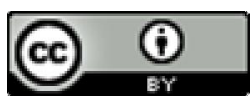

All the contents of this work, except where otherwise noted, is licensed under a Creative Commons Attribution $\underline{4.0 \text { International license. }}$

Todo o conteúdo deste trabalho, exceto quando houver ressalva, é publicado sob a licença Creative Commons Atribição 4.0.

Todo el contenido de esta obra, excepto donde se indique lo contrario, está bajo licencia de la licencia Creative Commons Reconocimento 4.0. 


\section{3}

AÇÕES POSITIVAS PARA CONSERVAÇÃO E RESTAURAÇÃO DA MATA ATLÂNTICA NOS ESTADOS E MUNICÍPIOS 
$r_{t}^{t}$ onsiderando a extrema necessidade de conservação e restauração da Mata Atlântica, uma série de ações poderia ser tomada pelo poder público para garantir a conservação dos últimos remanescentes e a restauração das áreas importantes para conexão dos fragmentos florestais remanescentes. A união, os estados e os municípios podem atuar bem além do aspecto legal neste sentido.

As ações de conservação estão voltadas, principalmente, para a criação de Unidades de Conservação, hoje todos os grandes fragmentos florestais de floresta atlântica, em bom estado de conservação (em estágio avançado de regeneração e florestas primárias), deveriam constituir unidades de conservação. Vemos muitas áreas com mais de 1.000 hectares, que deveriam ser preservadas, ainda sofrendo ameaças. Podemos observar que, no domínio da Mata Atlântica, são poucos estes fragmentos (o que poderia gerar uma ação rápida de conservação, transformação em UC), e esta área ainda pode abrigar muitas espécies da flora e da fauna, incluindo espécies raras, endêmicas e ameaçadas de extinção.

Dentro das ações de conservação, observamos que a caça predatória ainda é uma ameaça constante para a conservação da Mata Atlântica, em especial, quando consideramos a grande interação/inter-relação entre flora e fauna neste Bioma. Mesmo nos dias de hoje, com toda tecnologia, comunicação, facilidade de acesso às informações, a caça ainda é tradição no meio rural das áreas do Bioma Mata Atlântica, praticamente, em toda sua extensão. Ações de fiscalização mais intensiva e de conscientização ambiental deviam ser intensificadas e planejadas para coibir e paralisar, completamente, estas ações de destruição da fauna da Mata Atlântica. Observamos que, mesmo dentro de Unidades de Conservação, esta prática é constante e ocorre no dia a dia. Em florestas particulares, de igual forma, tal prática é contínua, assim deveriam existir ações de fiscalização e conscientização ambientais em todos os níveis, fiscalizadas pelos órgãos responsáveis de nível federal (IBAMA), estaduais de meio ambiente e, principalmente, pelas secretarias de meio ambiente municipais. Um mapeamento dos pontos onde ocorrem as caçadas e um planejamento de ação para proibir definitavamente estas ações deveriam ter caráter de urgência.

Destacamos, neste item, a criação de Reservas Particulares de Proteção Natural (RPPN), que são unidades de conservação 
particulares, quando o proprietário, por iniciativa própria e espontânea, manifesta o interesse de destinar parte de sua propriedade para conservação ambiental. Estas iniciativas deveriam ter mais apoios que os previstos na legislação (praticamente somente isenção de ITR), visando incentivar os proprietários a criarem estas UC's particulares, a alternativa de pagamento de serviços ambientais (PSA) pode ser uma solução para dar maior incentivo à criação destas reservas particulares.

Outra forte ação que é necessária em todos os níveis de governo (federal, estadual e municipal) é a de restauração ecológica. Esta deve ser planejada, tomando como base, principalmente, o estudo da paisagem regional, de tal forma que permita a conexão dos principais fragmentos florestais do município, estado e união. O planejamento de paisagens e a disponibilidade de imagens de satélite de alta resolução são ferramentas que podem tornar esta ação mais eficiente. Uma importante iniciativa, neste sentido, é a implantação dos "Bancos de Áreas destinadas para Restauração Florestal", estas áreas cadastradas, através dos estudos de paisagem, realizados no município, assim como o interesse dos proprietários de terra, podem facilitar ações de restauração, principalmente, na acepção de conectar fragmentos florestais e formar corredores ecológicos, assim como restaurar matas ciliares importantes para conservação dos recursos hídricos.

Podemos observar, nos dias de hoje, várias iniciativas de financiamento e colocação de disponibilidade de recursos e financiamentos para ações de restauração ecológica e recuperação de áreas degradadas e perturbadas, assim torna-se cada vez mais necessário e urgente que todo município do domínio da floresta atlântica possa seu "Banco de Áreas Destinadas à Recuperação Ambiental". Este cadastro deve também conter potenciais produtores de mudas nativas e empresas com habilidade para executar plantios de restauração ecológica. A cadeia produtiva da restauração ecológica necessita ser formada em toda área de mata atlântica para que estas ações de restauração se tornem realidade e deixem de ser apenas marketing para se tornar algo e cientificamente real.

Neste planejamento ambiental de ações municipais, é muito importante conciliarmos as ações de intervenções necessárias nos ecossistemas (ações inevitáveis e necessárias para crescimento das cidades, implantação de grandes empreendimentos, obras sociais do governo etc.) com ações de conservação e recuperação ambiental, 
ou seja, instituir um grupo de ações práticas para compensação ambiental, todo dano ambiental causado resultaria em uma ação compensatória (já está legalmente previsto). Uma das estratégias que podem ser utilizadas nos municípios é a adoção de conjunto de práticas que podem vir a tornar condicionantes de todos os empreendimentos que serão implantados no território. Para empreendimentos onde se faz necessária a supressão de vegetação e é permitida legalmente esta prática (como exemplo, empreendimentos urbanísticos, em área urbana do município), podemos ter como condicionantes ambientais a obrigatoriedade da prática de resgate e salvamente de espécies da flora e fauna em todas as áreas, onde está previsto supressão de vegetação e outras intervenções sobre flora e fauna, assim como plantios de compensação em área igual ou maior a que está sendo suprimida. A associação de práticas de salvamento/resgate aos trabalhos de restauração ecológica é muito bem vinda, estes propágulos que normalmente iriam ser destruídos com a supressão de vegetação podem enriquecer áreas de restauração ecológica próxima à área de supressão. Vários propágulos também podem ser levados para viveiro de produção de mudas até ganhar condições de retornarem e serem reintroduzidos em plantios de restauração ou em áreas naturais similares.

A "Lei da Mata Atlântica" - Lei n 11.428, de 22 de dezembro de 2006 -, no seu artigo 7, apresenta condições que devem nortear as ações de proteção e de utilização do Bioma Mata Atlântica. Estas condições visam assegurar a manutenção e a recuperação da biodiversidade (vegetação e fauna) e o regime hídrico para as gerações presentes e futuras, bem como estimular a pesquisa e a difusão de tecnologias de manejo sustentável. Esta lei da Mata Atlântica institui a implantação dos planos municipais para Conservação e Recuperação da Mata Atlântica, dado que são abertas as possibilidades dos municípios atuarem diretamente na defesa, conservação e recuperação da vegetação nativa da Mata Atlântica. Os Planos Municipais para Conservação e Recuperação da Mata Atlântica (PMMA) tornam-se uma ferramenta fundamental para ações dentro do território do município. Várias ações, colocadas aqui, podem ser implementadas através das diretrizes dadas por este plano.

Iniciativas de incentivo de plantio de áreas florestais de Mata Atlântica devem se multiplicar, visando promover o retorno planejado da floresta atlântica. Citamos atitudes louváveis, neste 
sentido, como o programa Click Árvore da SOS Mata Atlântica, que já completa 13 anos de atividades de plantios de mudas de Mata Atlântica. No dia 01 de agosto de 2000, quando a Fundação SOS Mata Atlântica e o Instituto Vidágua lançaram o Clickarvore, o número de brasileiros que utilizavam a Internet era de aproximadamente 5 milhões de pessoas, e, no início do programa, tinha uma média de 2.000 acessos diários (FUNDAÇÃO SOS MATA ATLÂNTICA, 2000). Estes programas de recuperação em REDES têm crescido e são iniciativas importantes para envolver pessoas, cidadãos e multiplicar empreendimentos de restauração florestal. 